\title{
A Feasibility Analysis of Black-Scholes-Merton Differential Equation Model for Stock Option Pricing by Using Historical Volatility : With Reference to Selected Stock Options Traded in NSE
}

\author{
Dr. Rekha Kala A.M. \\ Professor of Finance \\ Dr. Shyam Lal Dev Pandey (Corresponding Author) \\ Associate Professor of Finance, Alliance University \\ School of Business, Bangalore, Karnataka, India \\ E-mail: shyamlaldev@gmail.com,shyamlal.pandey@alliance.edu.in
}

Received: June 29, 2012 Accepted: July 25, $2012 \quad$ Published: December 1, 2012

doi:10.5296/ajfa.v4i2.2022 URL: http://dx.doi.org/10.5296/ajfa.v4i2.2022

\begin{abstract}
In today's financial world there is a great need to predict the value of the assets, using which strategic decisions can be made to make short term or long term capital gains. Due to the dynamic and uncertain nature of the financial markets, the prediction of the asset prices are really difficult. Many models have been developed to predict the option prices in the financial market. The certainity of these models to predict the option prices to the most accurate level or to the level of minimum deviation is questionable. This study is aimed at analyzing the feasibility of Black - Scholes - Merton differential equation model for stock option pricing in Indian stock exchanges. The result of this study can be used to predict the suitability of using Black - Scholes - Merton differential equation model to predict stock option prices in Indian market. Further the regression analysis has been used to see the impact of time to expiry over the option price and anova test has been used to check whether the mean difference between expected price as computed by Black - Scholes - Merton differential equation model and actual price have any significant difference. The result of analysis found that Black - Scholes Merton model is more usefull in call option pricing than the put option pricing and also impact of timing is more relevenat for put option pricing than for call option pricing.
\end{abstract}


Keywords: Option, Black-Scholes - Merton, Pricing, Differential equation, NSE, Stock 


\section{Introduction}

Finance is one of the most dynamic area in the modern corporate arena and in a real sense, it is cornerstone of the free enterprise system. Due to high volatility and uncertain behaviour financial instruments have become complex and it is undergoing constant change in response to shifts in economic conditions. In today's highly volatile and dynamic world, financial markets have continued to produce a multitude of new products including many new forms of derivatives, alternative risk transfer products, exchange traded funds, and variants of tax-deductible equity.

The days have gone when simple business graduates were managing the world of corporate finance now area of finance is controlled by mathematicians and computer scientists.

In the last 30 years derivatives have become increasignly important in finance. Derivative products serve the vitally important economic functions of price discovery in the underlying market and risk management tools by facilitating the trading of risks among the market participants. Pricing is very important in options contract. Options traders use a pricing formula to determine call and put options prices. Many models have been developed to predict the option prices in the financial market. The certainity of these models to predict the option prices to the most accurate level or to the level of minimum deviation is questionable. The Black-Scholes model is considered as a very elegant piece of research into option prices. The model uses ideas from the Brownian motion and other theories based on 'random walk'. The model involves certain inherent assumptions such as log-normal distribution of the stock price, constant volatility during the tenure of the option, interest rate, exercise price and stock price. In the modern finance theory Black - Scholes - Merton differential equation model (1970) has prominent place specially after 1997 when Robert Merton and Myron Scholes were awarded the Nobel prize for economics. Sadly, Fischer Black died in 1995, otherwise he too have been one of the receipient of the prize (Hull \& Basu 2010).

\section{Black-Scholes model}

The data inputs to this model are current stock price, exercise price, expected volatility, interest rate and time to expiry. In this model pricing of an option involves constructing a replicating hedge portfolio comprising a long position in stock and a short position in a zero-coupon bond. The hedge portfolio will be constituted in such a way that at any given point of time its value will always be equal to the option's price at that time. The proportion of stocks and bonds will be determined by the Black-Scholes formula.As the formula consists of constantly changing factors, the portfolio mix has to be constantly adjusted. So the portfolio is called as dynamic portfolio and the act of maintaining the portfolio in balance is called as hedge rebalancing.

\section{BLACK - SCHOLES FORMULA FOR OPTION PRICING:}

$$
\begin{gathered}
C=S * N(d 1)-X * e^{-r t} * N(d 2) \\
P=X * e^{-r t} * N(-d 2)-S * N(-d 1)
\end{gathered}
$$




$$
\begin{gathered}
d 1=\frac{\ln (S / X)+\left(r+\frac{\sigma^{2}}{2}\right) * t}{\sigma * \sqrt{t}} \\
d 2=d 1-\sigma * \sqrt{t}
\end{gathered}
$$

Here in this formula,

$\mathrm{N}()=$. cumulative normal distribution function

$\ln =$ Natural logarithm

$\mathrm{S}=$ Spot price of stock

$\mathrm{X}=$ Exercise price of the option

$\mathrm{r}=$ Annual risk free rate of return

$t=$ Time to expiry of the option

$\sigma=$ Annual volatility of the stock

One of the assumptions and limitations of the Black - Scholes model is that the asset pays zero dividend. This cannot be the case with all the assets. In 1973, Robert Merton provided an analysis of Black \& Scholes model in which he suggested adjustments to take care of dividend payments. So this helped in over coming one of the limitations of Black - Scholes model.

\section{BLACK - SCHOLES - MERTON FORMULA:}

$$
\begin{gathered}
C=S * e^{-d t} * N(d 1)-X * e^{-r t} * N(d 2) \\
P=X * e^{-r t} * N(-d 2)-S * e^{-d t} * N(-d 1) \\
d 1=\frac{\ln (S / X)+\left(r-d+\frac{\sigma^{2}}{2}\right) * t}{\sigma * \sqrt{t}} \\
d 2=d 1-\sigma * \sqrt{t}
\end{gathered}
$$

Here in this case,

$\mathrm{d}=$ Annual dividend yield

\section{Problem Statement}

Using the Black - Scholes - Merton model to calculate the expected call option and put option prices for various expiry dates through data gathered from NSE website for stock options and compare it with the actual stock option price, to find out whether Black - Scholes Merton(B-S-M) model is feasible in predicting option prices in Indian market.

\section{Objectives}

1. To test the viability of Scholes - Merton model using real time data from NSE. 
2. To test the feasibility of Black - Scholes - Merton model in Indian scenario by using real time data from NSE.

3. To measure the impact of changes in time to expiry on the option prices using Black Scholes - Merton model.

4. To test the significance of the difference between the mean of estimated price and actual price.

\section{Research Design}

In this research paper, real time values are taken from the NSE website and the components of Black - Scholes - Merton model are calculated and substituted in formula and we arrive at the expected price of option. We also take the actual price of the option from NSE website and compare it with the calculated price of option. Through this we come to a conclusion whether Black-Scholes-Merton model is feasible for option pricing in India.

\section{Data Collection Methods and Sources}

This research is based on real time secondary data collected from National Stock Exchange (NSE) derivative segment. Other relevant information has been collected from past studies on similar subject. Real time data has been taken for each trading day starting with 16/8/2011 and ending with 29/9/2011. To make this study more feasible 5 different stocks representing 5 different industries has been picked up on the basis of market capitalization and volume of trade.

\section{Tools of Analysis}

Study is based upon application of black scholes model and testing of this model in indian derivative segment. For the testing purpose Paired Samples Test, Regression Analysis and ANOVA has been used. Other statistical tools used in study include Standard deviation, beta, ratio etc.

\section{Hypotheses}

H1: There is no significant difference between the expected options price computed by B-S-M model by taking historical volatrility and actual price determined by market forces.

H2: There is no impact of length of time to expiry on the difference between expected and actual options price.

H3: Black- Schole - Merton model gives identical result for both call option price as well as put otion price.

\section{Literature Review}

Number of studies can be traced out on black scholes model. Here we are starting with Black and Scholes (1973) study that was based on an empirical investigations and conclude bias within the Black-Scholes model in terms of moneyness and maturity. MacBeth and 
Merville (1980) ${ }^{1}$ tested the Black - Scholes model against the constant elasticity of variance (CEV) model, which assumes volatility changes when the stock prices changes. Blattberg and Gonedes $(1974)^{2}$ suggest volatility of the underlying stock is stochastic and random.

In the modern finance theory Black - Scholes - Merton differential equation model (1970) has prominent place specially after 1997 when Robert Merton and Myron Scholes were awarded the Nobel prize for economics. Sadly, Fischer Black died in 1995, otherwise he too have been one of the receipient of the prize (Hull \& Basu 2010).

Bhattacharya, M. $(1980)^{3}$ in his paper Empirical properties of the Black Scholes formula under ideal conditions, examined the "Black-Scholes" method for pricing, its fundamentals and its applications in the 21 st century economy.

Radu, Turcan $(2010)^{4}$,in their paper "BLACK-SCHOLES MODEL USED TO EVALUATE STOCKS OPTIONS" mentioned that Partial differential equation, parabolic Black-Scholes type: $\partial \mathrm{V} / \partial \mathrm{t}+1 / 2 \sigma^{2} \mathrm{~S}^{2} \partial^{2} \mathrm{~V} / 2 \mathrm{~S}^{2}+\mathrm{rS} \partial \mathrm{V} / \partial \mathrm{S}-\mathrm{rV}=0$ is used in evaluating equity options, that paying constant and continue dividends or in evaluate options in which interest rate, volatility and dividend are dependent on time.

Heston, Steven L.; Loewenstein, Mark; Willard, Gregory A (2007) ${ }^{5}$ found that The Black-Scholes-Merton option valuation method involves deriving and solving a partial differential equation (PDE). But this method can generate multiple values for an option. We provide new solutions for the Cox-Ingersoll-Ross (CIR) term structure model, the constant elasticity of variance (CEV) model, and the Heston stochastic volatility model. Multiple solutions reflect asset pricing bubbles, dominated investments, and (possibly infeasible) arbitrages. We provide conditions to rule out bubbles on underlying prices. If they are not satisfied, put-call parity might not hold, American calls have no optimal exercise policy, and lookback calls have infinite value. We clarify a longstanding conjecture of Cox, Ingersoll, and Ross.

Scott McKenzie, Dionigi Gerace, Zaffar Subedar, (2007) ${ }^{6}$ in their paper 'An empirical investigation of the Black-Scholes model: Evidence from the Australian stock excahnge' evaluates the probability of an exchange traded European call option being exercised on

\footnotetext{
${ }^{1}$ MacBeth, J. D., and Merville, L. J. (1980). Tests of the Black-Scholes and Cox call option valuation models. Journal of finance, 35(2), 285-301.

2 Blattberg, R. C., and Gonedes, J. (1974). A comparison of the stable and student distributions as statistical models for stock prices. Journal of business, 47(2), 244- 280.

${ }^{3}$ Bhattacharya, M. (1980). Empirical properties of the Black Scholes formula under ideal conditions. Journal of financial and quantitative analysis, 15(5), 1081-1105.

4 Turcan. (2010) Annals of the University of Oradea, Economic Science Series, 2010, Vol. 19 Issue 2, p795-799,

${ }_{5}^{5}$ Heston, Steven L.; Loewenstein, Mark; Willard, Gregory A.(2007), Review of Financial Studies, Mar2007, Vol. 20 Issue 2, p359-390, 32p

${ }^{6}$ McKenzie, S.; Gerace, D.; and Subedar, Z., (2007)An empirical investigation of the Black-Scholes model:evidence from the Australian Stock Exchange, Australasian Accounting Business and Finance Journal, 1(4), 2007.
} 
ASX200 Option Index. Using single-parameter estimates of factors within the B \& S model, this paper utilises qualitative regression and a maximum likelihood approach. Results indicate that the B \& S model is statistically significant at the $1 \%$ level and it also provide evidence that the use of implied volatility and a jump-diffusion approach, which increases the tail properties of the underlying lognormal distribution, improves the statistical significance of the $B \& S$ model.

Espen Gaarder Haug \& Nassim Nicholas Taleb (2008) ${ }^{7}$ in their paper "Why We Have Never Used the Black-Scholes-Merton Option Pricing Formula" emphasized on the gap between finance theory and practicle. They further narated that Option hedging, pricing, and trading is neither philosophy nor mathematics. It is a rich craft with traders learning from traders (or traders copying other traders) and tricks developing under evolution pressures, in a bottom-up manner. This study is aimed at analyzing the feasibility of Black - Scholes - Merton differential equation model for stock option pricing in Indian Context. The result of this study can be used to predict the suitability of using Black - Scholes - Merton differential equation model to predict stock option prices in Indian market. Further the indipendent $t$ test has been used to check whether the mean difference between expected price as computed by Black Scholes - Merton differential equation model and ctual price have any significant difference or saying of Espen Gaarder Haug \& Nassim Nicholas Taleb is correct.

Chaudhury and Jason (1996) examined the behavior of European option price and the Black-Scholes model bias when stock returns follow a GARCH $(1,1)$ process. The GARCH option price is not preference neutral and depends on the unit risk premium (1) as well as the two GARCH $(1,1)$ process parameters (a1 ,b1). Deep-out-of the-money and short maturity options are an exception. The variance persistence parameter, $\mathrm{g}=\mathrm{a} 1+\mathrm{b} 1$, has a material bearing on the magnitude of the Black-Scholes model bias. The risk preference parameter, 1, on the other hand, determines the so called "leverage effect" and can be important in determining the direction of the Black-Scholes model bias.

Heston and Nandi (2000) ${ }^{8}$ in their paper developed a closed-form option valuation formula for a spot asset whose variance follows a $\operatorname{GARCH}(\mathrm{p}, \mathrm{q})$ process that can be correlated with the returns of the spot asset. The single lag version of this model contains Heston's stochastic volatility model as a continuous-time limit. Empirical analysis on S\&P500 index options shows that the out-of-sample valuation errors from the single lag version of the GARCH model are substantially lower than the ad hoc Black-Scholes model that uses a separate implied volatility for each option to fit to the smirk/smile in the implied volatilities.

7 Espen Gaarder Haug \& Nassim Nicholas Taleb (2008) in their paper "Why We Have Never Used the Black-Scholes-Merton Option Pricing Formula, can be downloaded from:

http://chineseactuary.groupsite.com/uploads/files/x/000/00e/45c/Why_We_Have_Never_Used_the_Bl ack-Scholes-Merton_Option_Pricing_Formula.pdf

${ }^{8}$ Heston, SL; Heston, Steven L.; Nandi, S; Nandi, Saikat(2000) A closed-form GARCH option valuation model, Review of Financial Studies, Fall2000, Vol. 13 Issue 3 
Lehar, Scheicher and Schittenkopf (2002) ${ }^{9}$ examined the out-of-sample performance of two common extensions of the Black-Scholes framework, namely a GARCH and a stochastic volatility option pricing model.

Christoffersen, Peter; Heston, Steve; Jacobs, Kris (2006) ${ }^{10}$ found that Index option prices differ systematically from Black-Scholes prices. Out-of-the-money put prices (and in-the-money call prices) are relatively high compared to the Black-Scholes price. Motivated by these empirical facts, the authors develop a new discrete-time dynamic model of stock returns with Inverse Gaussian innovations. The model allows for conditional skewness as well as conditional heteroskedasticity and a leverage effect. The paper presents an analytic option pricing formula consistent with this stock return dynamic.

Barone-Adesi, Giovanni; Engle, Robert F.; Mancini, Loriano. (2008 ${ }^{11}$ their work analyzes a new method for pricing options based on GARCH models with filtered historical innovations. In an incomplete market framework the authors allow for different distributions of the historical and the pricing return dynamics enhancing the model flexibility to fit market option prices. An extensive empirical analysis based on S\&P 500 index options shows that this model outperforms other competing GARCH pricing models and ad hoc Black-Scholes models.

Singh, Ahmad and Pachori (2011) ${ }^{12}$ The research work empirically investigates out of sample forecasting performance of closed-form discrete time Heston and Nandi GARCH option pricing model with benchmark Black-Scholes and its version Practitioner Black-Scholes model for pricing S\&P CNX Nifty 50 index option of India, relative to market price using error metrics, moneyness-maturity wise. In this research work, the authors first find the parameters of the models analytically, and then used them to produce reliable predictions of the next-day option prices. The results show that Practitioner Black-Scholes model outperforms the other two models. It is not only outperforming but also reducing the price bias between model and market greatly, despite the fact that execution of GARCH is very complex as compared to Practitioner Black-Scholes and Black-Scholes. The Practitioner Black-Scholes reduces price bias significantly, in 12 out of 15 moneyness-maturity groups.

Rotkowski, Aaron M.(2011) ${ }^{13}$, in their research paper entitled Estimating Stock Price Volatility in the Black-Scholes-Merton Model found that The BSM model is a common

\footnotetext{
${ }^{9}$ Lehar, Alfred; Scheicher, Martin; Schittenkopf, Christian. (2002) GARCH vs. stochastic volatility: Option pricing and risk management, Journal of Banking \& Finance, Mar2002, Vol. 26 Issue 2/3, p323, 23p,

10 Christoffersen, Peter; Heston, Steve; Jacobs, Kris. (2006), Option valuation with conditional skewness, Journal of Econometrics, Mar/Apr2006, Vol. 131 Issue 1/2, p253-284,

11 Barone-Adesi, Giovanni; Engle, Robert F.; Mancini, Loriano(2008), A GARCH Option Pricing Model with Filtered Historical Simulation., Review of Financial Studies, May2008, Vol. 21 Issue 3, p1223-1258,

12 Singh, Vipul Kumar; Ahmad, Naseem; Pachori, Pushkar(2011), Empirical analysis of GARCH and Practitioner Black-Scholes Model for pricing S\&P CNX Nifty 50 index options of India., Decision (0304-0941), Aug2011, Vol. 38 Issue 2, p51-67,

13 Rotkowski, Aaron M.(2011), Estimating Stock Price Volatility in the Black-Scholes-Merton Model, Value Examiner, Nov/Dec2011, p13-19, 7p,
} 
approach used by valuation analysts to compute the fair market amount of non-traded stock options made by closely held businesses. This model consists of 5 fundamental parts including option time to expiration, risk-free interest rate, and current price of the underlying stock.

\section{Limitations of Study:}

Though study is based upon the analysis of real time data and aim to produce most feasible results for Indian market situatio. Study is based upon certain assumptions and these assumption can be regarded as the limitation of study. These are:

i. There is no difference between historical volatility and implied volatility.

ii. Daily fluctuation of option prices between periods have not taken in the study.

iii. Dividend yield is annual dividend yield and remain same for study period.

iv. Volatility remain same for study period .

v. Rate of interest (repo rate) does not change during the analysis period.

\section{Data Analysis - Real Time}

Data obtained from F\&O segment of NSE has been tested for the feasibility study of Black-Scholes-Merton Model in Indian context. For the analysis purpose Historical volatility has been computed by considering the stock prices movement between the dates 1-Jul-2010 and 30-Jun-2011. For the computation of annual volatility first daily return has been computed by using $\ln (\mathrm{St} / \mathrm{St}-1)$ then daily standard deviation has been converted in annual volatility by using following formula:

Annual Volatility $(\sigma)=$ Daily $\sigma * \sqrt{ }$ Days in a Year

Annual dividend yield has been computed by considering the total dividends paid in the year 2010-2011 and considering the market price of the stock on 31-Mar-2011. 


\section{Macrothink}

Asian Journal of Finance \& Accounting

ISSN $1946-052 \mathrm{X}$

2012, Vol. 4, No. 2

Table 1. Difference between an expected and actual price of a call option expiring in 7 days

\begin{tabular}{|l|l|l|l|l|l|}
\hline DATA & JP Associate & RIL & SBI & HINDALCO & INFY \\
\hline Underlying Price & 67.00 & 786.35 & $1,937.55$ & 139.40 & $2,352.60$ \\
\hline Exercise Price & 70.00 & 780.00 & $2,300.00$ & 180.00 & $2,400.00$ \\
\hline Consideration Date & $9 / 22 / 2011$ & $9 / 22 / 2011$ & $9 / 22 / 2011$ & $9 / 22 / 2011$ & $9 / 22 / 2011$ \\
\hline Expiry Date & $9 / 29 / 2011$ & $9 / 29 / 2011$ & $9 / 29 / 2011$ & $9 / 29 / 2011$ & $9 / 29 / 2011$ \\
\hline Historical Volatility & $43.56 \%$ & $23.71 \%$ & $31.45 \%$ & $35.50 \%$ & $23.34 \%$ \\
\hline Risk Free Rate & $8.30 \%$ & $8.30 \%$ & $8.30 \%$ & $8.30 \%$ & $8.30 \%$ \\
\hline Dividend yield & $0.86 \%$ & $0.76 \%$ & $1.08 \%$ & $0.72 \%$ & $1.85 \%$ \\
\hline Time(Years) & 0.02 & 0.02 & 0.02 & 0.02 & 0.02 \\
\hline d1 & -0.672307 & 0.3073922 & -3.883767 & -5.145161 & -0.356009 \\
\hline $\mathrm{N}(\mathrm{d} 1)$ & 0.2507 & 0.6207 & 0.0001 & 0.0000 & 0.3609 \\
\hline $\mathrm{d} 2$ & -0.7326 & 0.2746 & -3.9273 & -5.1943 & -0.4052 \\
\hline $\mathrm{N}(\mathrm{d} 2)$ & 0.2319 & 0.6082 & 0.0000 & 0.0000 & 0.3427 \\
\hline Expected Price & 0.5871 & 14.4184 & 0.0010 & 0.0000 & 27.6780 \\
\hline Actual Price & 0.9 & 18.9 & 0.75 & 0.1 & 25.7 \\
\hline Difference in value & 0.3129 & 4.4816 & 0.7490 & 0.1000 & 1.9780 \\
\hline$\%$ Difference & 34.76667 & 23.71217 & 99.86667 & 100 & 7.14647012 \\
\hline
\end{tabular}

Source: computed on the basis of realtime data obtained from NSE Derivative segment.

Table No. 1 shows difference between an expected and actual price of a call option expiring in 7 days. Expected price has been computed by using Using the Black - Scholes - Merton model which is based on 5 factor viz. Spot price of stock, Exercise price of the option, Annual risk free rate of return, Time to expiry of the option, Annual volatility of the stock. Table shows that in case of short period ( 7 days) there is significant difference between expected and actual call option price. The difference is m,aximum in case of Hindalco call option price where expected price is absent due to zero value of $\mathrm{N}(\mathrm{d} 1)$ and $\mathrm{N}(\mathrm{d} 2)$, while the comperative difference is less in case of INFY Call option i.e. Rs. 1.9780 (27.6780-25.7) 7.15\% only . 


\section{Macrothink}

Asian Journal of Finance \& Accounting

ISSN 1946-052X

2012, Vol. 4, No. 2

Table 2. Price difference between an expected and actual price of a call option expiring in 15 days

\begin{tabular}{|l|l|l|l|l|l|}
\hline DATA & JP Associate & RIL & SBI & HINDALCO & INFY \\
\hline Underlying Price & 68.35 & 825.40 & $1,826.75$ & 145.10 & $2,351.65$ \\
\hline Exercise Price & 70.00 & 780.00 & $2,300.00$ & 180.00 & $2,400.00$ \\
\hline Consideration Date & $9 / 14 / 2011$ & $9 / 14 / 2011$ & $9 / 14 / 2011$ & $9 / 14 / 2011$ & $9 / 14 / 2011$ \\
\hline Expiry Date & $9 / 29 / 2011$ & $9 / 29 / 2011$ & $9 / 29 / 2011$ & $9 / 29 / 2011$ & $9 / 29 / 2011$ \\
\hline Historical Volatility & $43.56 \%$ & $23.71 \%$ & $31.45 \%$ & $35.50 \%$ & $23.34 \%$ \\
\hline Risk Free Rate & $8.30 \%$ & $8.30 \%$ & $8.30 \%$ & $8.30 \%$ & $8.30 \%$ \\
\hline Dividend yield & $0.86 \%$ & $0.76 \%$ & $1.08 \%$ & $0.72 \%$ & $1.85 \%$ \\
\hline Time(Years) & 0.04 & 0.04 & 0.04 & 0.04 & 0.04 \\
\hline d1 & -0.19134995 & 1.2655302 & -3.534911 & -2.915668 & -0.209978 \\
\hline Nd1 & 0.4241 & 0.8972 & 0.0002 & 0.0018 & 0.4168 \\
\hline d2 & -0.2797 & 1.2175 & -3.5987 & -2.98776 & -0.2819 \\
\hline Nd2 & 0.3899 & 0.8883 & 0.0002 & 0.0014 & 0.3890 \\
\hline Expected Price & 1.7807 & 49.7800 & 0.0058 & 0.0053 & 49.1178 \\
\hline Actual Price & 2.05 & 56.15 & 2.55 & 0.25 & 52.5 \\
\hline Difference in value & 0.2693 & 6.3700 & 2.5442 & 0.2447 & 3.3822 \\
\hline \% Difference & 13.13659 & 11.34461 & 99.77255 & 97.88 & 6.44228 \\
\hline
\end{tabular}

Source: computed on the basis of realtime data obtained from NSE Derivative segment.

Table 2 indicates that increase in the time to expiry brings positive impact on call option prices of all selected underlaying stock. Due to increase in time to expiry call option price has been incresed because of time value of option and relative difference has been minimized in terms of difference between expected price and actual price. The difference in the value has been highest in case of RIL call option price with Rs. 6.37 While lowest in HINDALCO call option with .2447 as a percentage difference in Infosys Call option is lowest with $6.44 \%$ and highest in SBI call option price with $99.77 \%$. 
Table 3. The price difference between an expected and actual price of a call option expiring in 30 days

\begin{tabular}{|l|l|l|l|l|l|}
\hline DATA & JP Associate & RIL & SBI & HINDALCO & INFY \\
\hline Underlying Price & 58.30 & 755.05 & $1,938.60$ & 144.10 & $2,296.25$ \\
\hline Exercise Price & 70.00 & 780.00 & $2,300.00$ & 180.00 & $2,400.00$ \\
\hline Consideration Date & $8 / 29 / 2011$ & $8 / 29 / 2011$ & $8 / 29 / 2011$ & $8 / 29 / 2011$ & $8 / 29 / 2011$ \\
\hline Expiry Date & $9 / 29 / 2011$ & $9 / 29 / 2011$ & $9 / 29 / 2011$ & $9 / 29 / 2011$ & $9 / 29 / 2011$ \\
\hline Historical Volatility & $43.56 \%$ & $23.71 \%$ & $31.45 \%$ & $35.50 \%$ & $23.34 \%$ \\
\hline Risk Free Rate & $8.30 \%$ & $8.30 \%$ & $8.30 \%$ & $8.30 \%$ & $8.30 \%$ \\
\hline Dividend yield & $0.86 \%$ & $0.76 \%$ & $1.08 \%$ & $0.72 \%$ & $1.85 \%$ \\
\hline Time (Years) & 0.08 & 0.08 & 0.08 & 0.08 & 0.08 \\
\hline d1 & -1.32745587 & -0.343263 & -1.752344 & -2.036193 & -0.322466 \\
\hline Nd1 & 0.0922 & 0.3657 & 0.0399 & 0.0209 & 0.3735 \\
\hline d2 & -1.4544 & -0.4124 & -1.8440 & -2.1397 & -0.4259 \\
\hline Nd2 & 0.0729 & 0.3400 & 0.0326 & 0.0162 & 0.3351 \\
\hline Expected Price & 0.3018 & 12.5778 & 2.7623 & 0.1109 & 57.8701 \\
\hline Actual Price & 0.45 & 16 & 6.5 & 0.5 & 47.15 \\
\hline Difference in value & 0.1482 & 3.4222 & 3.7377 & 0.3891 & 10.7201 \\
\hline \% Difference & 32.93333 & 21.38875 & 57.50308 & 77.82 & 22.73616119 \\
\hline
\end{tabular}

Source: computed on the basis of realtime data obtained from NSE Derivative segment.

Table 4. The price difference between an expected and actual price of a call option expiring in 43 days

\begin{tabular}{|l|l|l|l|l|l|}
\hline DATA & JP Associate & RIL & SBI & HINDALCO & INFY \\
\hline Underlying Price & 57.15 & 759.15 & $2,196.95$ & 144.35 & $2,399.30$ \\
\hline Exercise Price & 70.00 & 780.00 & $2,300.00$ & 180.00 & $2,400.00$ \\
\hline Consideration Date & $8 / 16 / 2011$ & $8 / 16 / 2011$ & $8 / 16 / 2011$ & $8 / 16 / 2011$ & $8 / 16 / 2011$ \\
\hline Expiry Date & $9 / 29 / 2011$ & $9 / 29 / 2011$ & $9 / 29 / 2011$ & $9 / 29 / 2011$ & $9 / 29 / 2011$ \\
\hline Historical Volatility & $43.56 \%$ & $23.71 \%$ & $31.45 \%$ & $35.50 \%$ & $23.34 \%$ \\
\hline Risk Free Rate & $8.30 \%$ & $8.30 \%$ & $8.30 \%$ & $8.30 \%$ & $8.30 \%$ \\
\hline Dividend yield & $0.86 \%$ & $0.76 \%$ & $1.08 \%$ & $0.72 \%$ & $1.85 \%$ \\
\hline Time(Years) & 0.12 & 0.12 & 0.12 & 0.12 & 0.12 \\
\hline d1 & -1.2060949 & -0.177559 & -0.285489 & -1.654948 & 0.1223442 \\
\hline Nd1 & 0.1139 & 0.4295 & 0.3876 & 0.0490 & 0.5487 \\
\hline d2 & -1.3573 & -0.2599 & -0.3947 & -1.7782 & -0.0009 \\
\hline Nd2 & 0.0873 & 0.3975 & 0.3465 & 0.0377 & 0.4996 \\
\hline Expected Price & 0.4493 & 18.8363 & 61.4032 & 0.3465 & 126.3427 \\
\hline Actual Price & 0.7 & 22.6 & 55.05 & 0.7 & 81.25 \\
\hline Difference in value & 0.2507 & 3.7637 & 6.3532 & 0.3535 & 45.0927 \\
\hline \% Difference & 35.81429 & 16.65354 & 11.54078 & 50.5 & 55.49870769 \\
\hline
\end{tabular}


Source: computed on the basis of realtime data obtained from NSE Derivative segment.

\section{Observations}

In the case of call option with time to expiry of 7 days, the least difference in price was achieved in Hindalco Industries limited which is Rs.0.1000 and followed by JaiPrakash Associates with Rs.0.3129. In the case of call option with time to expiry of 15 days, the least difference in price was achieved in Hindalco Industries limited which is Rs.0.2447 and followed by JaiPrakash Associates with Rs.0.2693. In the case of call option with time to expiry of 30 days, the least difference in price was achieved in JaiPrakash associates which is Rs.0.1482 and followed by Hindalco Industries limited with Rs.0.3891.In the case of call option with time to expiry of 43 days, the least difference in price was achieved in JaiPrakash associates which is Rs.0.2507 and followed by Hindalco Industries limited with Rs.0.3535

Table 5. The price difference between an expected and actual price of a put option expiring in 7 days.

\begin{tabular}{|l|l|l|l|l|l|}
\hline DATA & JP Associate & RIL & SBI & HINDALCO & INFY \\
\hline Underlying Price & 67.00 & 786.35 & $1,937.55$ & 139.40 & $2,352.60$ \\
\hline Exercise Price & 70.00 & 780.00 & $2,100.00$ & 150.00 & $2,400.00$ \\
\hline Consideration Date & $9 / 22 / 2011$ & $9 / 22 / 2011$ & $9 / 22 / 2011$ & $9 / 22 / 2011$ & $9 / 22 / 2011$ \\
\hline Expiry Date & $9 / 29 / 2011$ & $9 / 29 / 2011$ & $9 / 29 / 2011$ & $9 / 29 / 2011$ & $9 / 29 / 2011$ \\
\hline Historical Volatility & $43.56 \%$ & $23.71 \%$ & $31.45 \%$ & $35.50 \%$ & $23.34 \%$ \\
\hline Risk Free Rate & $8.30 \%$ & $8.30 \%$ & $8.30 \%$ & $8.30 \%$ & $8.30 \%$ \\
\hline Dividend yield & $0.86 \%$ & $0.76 \%$ & $1.08 \%$ & $0.72 \%$ & $1.85 \%$ \\
\hline Time(Years) & 0.02 & 0.02 & 0.02 & 0.02 & 0.02 \\
\hline d1 & -0.672307 & 0.3073922 & -1.795032 & -1.436585 & -0.356009 \\
\hline Nd1 & 0.2507 & 0.6207 & 0.0363 & 0.0754 & 0.3609 \\
\hline d2 & -0.7326 & 0.2746 & -1.8386 & -1.4857 & -0.4052 \\
\hline Nd2 & 0.2319 & 0.6082 & 0.0330 & 0.0687 & 0.3427 \\
\hline Expected Price & 3.4868 & 6.9424 & 160.7120 & 10.6079 & 72.0953 \\
\hline Actual Price & 3.9 & 14.45 & 165 & 11.5 & 78.5 \\
\hline Difference in value & 0.4132 & 7.5076 & 4.2880 & 0.8921 & 6.4047 \\
\hline$\%$ Difference & 10.59487 & 51.95571 & 2.598788 & 7.757391 & 8.158853503 \\
\hline
\end{tabular}

Source: computed on the basis of realtime data obtained from NSE Derivative segment. 
Table 6. The price difference between an expected and actual price of a put option expiring in 15 days

\begin{tabular}{|l|l|l|l|l|l|}
\hline DATA & JP Associate & RIL & SBI & HINDALCO & INFY \\
\hline Underlying Price & 68.35 & 825.40 & $1,826.75$ & 145.10 & VALUE \\
\hline Exercise Price & 70.00 & 780.00 & $2,100.00$ & 150.00 & $2,351.65$ \\
\hline Consideration Date & $9 / 14 / 2011$ & $9 / 14 / 2011$ & $9 / 14 / 2011$ & $9 / 14 / 2011$ & $2,400.00$ \\
\hline Expiry Date & $9 / 29 / 2011$ & $9 / 29 / 2011$ & $9 / 29 / 2011$ & $9 / 29 / 2011$ & $9 / 14 / 2011$ \\
\hline Historical Volatility & $43.56 \%$ & $23.71 \%$ & $31.45 \%$ & $35.50 \%$ & $9 / 29 / 2011$ \\
\hline Risk Free Rate & $8.30 \%$ & $8.30 \%$ & $8.30 \%$ & $8.30 \%$ & $23.34 \%$ \\
\hline Dividend yield & $0.86 \%$ & $0.76 \%$ & $1.08 \%$ & $0.72 \%$ & $8.30 \%$ \\
\hline Time (Years) & 0.04 & 0.04 & 0.04 & 0.04 & $1.85 \%$ \\
\hline d1 & -0.19134995 & 1.2655302 & -2.108033 & -0.382229 & 0.04 \\
\hline Nd1 & 0.4241 & 0.8972 & 0.0175 & 0.3511 & -0.209978 \\
\hline d2 & -0.2797 & 1.2175 & -2.1718 & -0.4542 & 0.4168 \\
\hline Nd2 & 0.3899 & 0.8883 & 0.0149 & 0.3248 & -0.2819 \\
\hline Expected Price & 3.2165 & 1.9818 & 267.6310 & 6.8076 & 0.3890 \\
\hline Actual Price & 3.85 & 9.75 & 267 & 7.85 & 91.0826 \\
\hline Difference in value & 0.6335 & 7.7682 & 0.6310 & 1.0424 & 103.35 \\
\hline \% Difference & 16.45455 & 79.67385 & 0.23633 & 13.27898 & 113.4684341 \\
\hline
\end{tabular}

Source: computed on the basis of realtime data obtained from NSE Derivative segment.

Table 7. The price difference between an expected and actual price of a put option expiring in 30 days

\begin{tabular}{|l|l|l|l|l|l|}
\hline DATA & JP Associate & RIL & SBI & HINDALCO & INFY \\
\hline Underlying Price & 58.30 & 755.05 & $1,938.60$ & 144.10 & $2,296.25$ \\
\hline Exercise Price & 70.00 & 780.00 & $2,100.00$ & 150.00 & $2,400.00$ \\
\hline Consideration Date & $8 / 29 / 2011$ & $8 / 29 / 2011$ & $8 / 29 / 2011$ & $8 / 29 / 2011$ & $8 / 29 / 2011$ \\
\hline Expiry Date & $9 / 29 / 2011$ & $9 / 29 / 2011$ & $9 / 29 / 2011$ & $9 / 29 / 2011$ & $9 / 29 / 2011$ \\
\hline Historical Volatility & $43.56 \%$ & $23.71 \%$ & $31.45 \%$ & $35.50 \%$ & $23.34 \%$ \\
\hline Risk Free Rate & $8.30 \%$ & $8.30 \%$ & $8.30 \%$ & $8.30 \%$ & $8.30 \%$ \\
\hline Dividend yield & $0.86 \%$ & $0.76 \%$ & $1.08 \%$ & $0.72 \%$ & $1.85 \%$ \\
\hline Time (Years) & 0.08 & 0.08 & 0.08 & 0.08 & 0.08 \\
\hline d1 & -1.32745587 & -0.343263 & -0.759796 & -0.273911 & -0.322466 \\
\hline Nd1 & 0.0922 & 0.3657 & 0.2237 & 0.3921 & 0.3735 \\
\hline d2 & -1.4544 & -0.4124 & -0.8515 & -0.3774 & -0.4259 \\
\hline Nd2 & 0.0729 & 0.3400 & 0.1973 & 0.3529 & 0.3351 \\
\hline Expected Price & 11.5526 & 32.5359 & 170.3353 & 8.8275 & 148.3663 \\
\hline Actual Price & 14.35 & 38.75 & 178.4 & 11.15 & 140 \\
\hline Difference in value & 2.7974 & 6.2141 & 8.0647 & 2.3225 & 8.3663 \\
\hline \% Difference & 19.49408 & 16.03639 & 4.520572 & 20.8296 & 5.975928571 \\
\hline
\end{tabular}


Source: computed on the basis of realtime data obtained from NSE Derivative segment.

Table 8. The price difference between an expected and actual price of a put option expiring in 43 days.

\begin{tabular}{|l|l|l|l|l|l|}
\hline DATA & JP Associate & RIL & SBI & HINDALCO & INFY \\
\hline Underlying Price & 57.15 & 759.15 & $2,196.95$ & 144.35 & $2,399.30$ \\
\hline Exercise Price & 70.00 & 780.00 & $2,100.00$ & 150.00 & $2,400.00$ \\
\hline Consideration Date & $8 / 16 / 2011$ & $8 / 16 / 2011$ & $8 / 16 / 2011$ & $8 / 16 / 2011$ & $8 / 16 / 2011$ \\
\hline Expiry Date & $9 / 29 / 2011$ & $9 / 29 / 2011$ & $9 / 29 / 2011$ & $9 / 29 / 2011$ & $9 / 29 / 2011$ \\
\hline Historical Volatility & $43.56 \%$ & $23.71 \%$ & $31.45 \%$ & $35.50 \%$ & $23.34 \%$ \\
\hline Risk Free Rate & $8.30 \%$ & $8.30 \%$ & $8.30 \%$ & $8.30 \%$ & $8.30 \%$ \\
\hline Dividend yield & $0.86 \%$ & $0.76 \%$ & $1.08 \%$ & $0.72 \%$ & $1.85 \%$ \\
\hline Time (Years) & 0.12 & 0.12 & 0.12 & 0.12 & 0.12 \\
\hline d1 & -1.2060949 & -0.177559 & 0.5476283 & -0.175738 & 0.1223442 \\
\hline Nd1 & 0.1152 & 0.4295 & 0.7080 & 0.4302 & 0.5487 \\
\hline d2 & -1.3505 & -0.2599 & 0.4384 & -0.2990 & -0.0009 \\
\hline Nd2 & 0.0884 & 0.3975 & 0.6695 & 0.3825 & 0.4996 \\
\hline Expected Price & 12.5859 & 32.6161 & 46.5982 & 9.5349 & 108.4941 \\
\hline Actual Price & 11.15 & 38 & 55 & 12.4 & 79 \\
\hline Difference in value & 0.2439 & 5.3839 & 8.4018 & 2.8651 & 29.4941 \\
\hline$\%$ Difference & 2.187444 & 14.16816 & 15.276 & 23.10565 & 37.3343038 \\
\hline
\end{tabular}

Source: computed on the basis of realtime data obtained from NSE Derivative segment.

\section{Observations}

In the case of put option with time to expiry of 7 days, the least difference in price was achieved in JaiPrakash associates which is Rs.0.4132 and followed by Hindalco Industries limited with Rs.0.8921. In the case of put option with time to expiry of 15 days, the least difference in price was achieved in State Bank of India which is Rs.0.6310 and followed by JaiPrakash associates with Rs.0.6335 In the case of put option with time to expiry of 30 days, the least difference in price was achieved in Hindalco Industries limited which is Rs.2.3225 and followed by JaiPrakash Associates with Rs.2.7974. In the case of put option with time to expiry of 43 days, the least difference in price was achieved in JaiPrakash associates which is Rs.0.2438 and followed by Hindalco Industries limited with Rs.2.8651. So it can be seen that mostly in all cases JaiPrakash Associates and Hindalco Industries limited has occupied the first two ranks in providing least difference from the actual price.

It is also observed that JaiPrakash associates has got a historical annual volatility of $43.56 \%$ and hindalco Industries limited has got a historical annual volatility of $35.5 \%$ which are higher than the historical annual volatility of other three companies. 


\section{NI Macrothink}

It can also be seen that Infosys Limited which has historical volatility of $23.34 \%$ is the least of all companies in case of historical annual volatility and it has shown the highest difference in prices mostly when compared to other companies. The companies which have higher historical volatility, the Black-Scholes-Merton model can provide least difference between the expected and actual value of call and put options of that stock.

Market capitalization of Infosys Limited is Rs. 1,46,532.7 crores , Market capitalization of State Bank of India is Rs. 1,11,013.7 crores, Market capitalization of Reliance Industries limited is Rs.2,68,533.75 crores, Market capitalization of Hindalco Industries Limited is Rs.24,725.59 crores and Market capitalization of JaiPrakash associates is Rs.15586.76 crores. It can be seen that the average market capitalization of Hindalco Industries Limited and JaiPrakash associates is nearly 8.7 times lower than the market capitalization of other companies. So Black-Scholes-Merton model seems to provide least difference in price prediction for the companies with lower market capitalization.

Table 9. Table showing the average difference in option prices of five stock options

\begin{tabular}{|l|l|l|l|l|}
\hline \multirow{2}{*}{ Days to expiry } & \multicolumn{2}{|l|}{ Call option } & Put option \\
\cline { 2 - 5 } & average difference in price & \% Avg diff. & average difference in price & $\%$ Avg diff. \\
\hline 7 days & 1.5243 & 53.21 & 3.90112 & 16.21 \\
\hline 15 days & 2.56208 & 45.72 & 4.4685 & 44.62 \\
\hline 30 days & 3.68346 & 42.48 & 5.553 & 13.37 \\
\hline 43 days & 11.16276 & 34.00 & 9.27776 & 18.41 \\
\hline
\end{tabular}

\section{Observations}

From the above analysis it is found that the expected values vary significantly from the actual values. In the Table 9, it can be found that the percentage average difference in prices keeps on decreasing as the number of days to expiry increases. This shows that the accuracy of the Black-Scholes-Merton model in computation of call option prices increases as the number of days to expiry increases. It can also be found that the average difference in rupee prices for call options are mostly lower than the average difference in rupee prices for put options, while average percentage difference is not similar in all four cases as call option shows higher percentage differences compared to put option price. This shows that the prediction level of Black-Scholes-Merton model for a call option is higher than that of the put option. Regression analysis of difference in following section makes our inference more valid. 
Regression Analysis: Regression Value of Difference in Call Option prices

\begin{tabular}{|l|l|l|l|l|}
\hline Model & R & R Square & Adjusted R Square & Std. Error of the Estimate \\
\hline 1 & $.905(a)$ & .819 & .729 & 2.27955 \\
\hline
\end{tabular}

a Predictors: (Constant), Days

\section{ANOVA(b)}

\begin{tabular}{|l|l|l|l|l|l|l|}
\hline Model & & $\begin{array}{l}\text { Sum of } \\
\text { Squares }\end{array}$ & df & Mean Square & F & Sig. \\
\hline 1 & Regression & 47.059 & 1 & 47.059 & 9.056 & $.095(\mathrm{a})$ \\
\hline & Residual & 10.393 & 2 & 5.196 & & \\
\hline & Total & 57.452 & 3 & & & \\
\hline
\end{tabular}

a Predictors: (Constant), Days

b Dependent Variable: ECPRICEDIF

\section{Coefficients(a)}

\begin{tabular}{|l|l|l|l|l|l|l|}
\hline \multirow{2}{*}{ Model } & & \multicolumn{2}{|l|}{ Unstandardized Coefficients } & $\begin{array}{l}\text { Standardized } \\
\text { Coefficients }\end{array}$ & $\mathrm{t}$ & Sig. \\
\hline & & $\mathrm{B}$ & Std. Error & Beta & $\mathrm{B}$ & Std. Error \\
\hline 1 & (Constant) & -1.151 & 2.263 & & -.508 & .662 \\
\hline & Days & .248 & .082 & .905 & 3.009 & .095 \\
\hline
\end{tabular}

a Dependent Variable: ECPRICEDIF

(ii) Regression Value of Difference in Put Option prices:

\begin{tabular}{|l|l|l|l|l|}
\hline Model & R & R Square & Adjusted R Square & Std. Error of the Estimate \\
\hline 1 & .939 (a) & .881 & .822 & 1.01955 \\
\hline
\end{tabular}

a Predictors: (Constant), Days

ANOVA(b)

\begin{tabular}{|l|l|l|l|l|l|l|}
\hline Model & & Sum of Squares & df & Mean Square & F & Sig. \\
\hline 1 & Regression & 15.455 & 1 & 15.455 & 14.868 & $.061(\mathrm{a})$ \\
\hline & Residual & 2.079 & 2 & 1.039 & & \\
\hline & Total & 17.534 & 3 & & & \\
\hline
\end{tabular}

a Predictors: (Constant), Days

b Dependent Variable: EPPRICEDIF 
Coefficients(a)

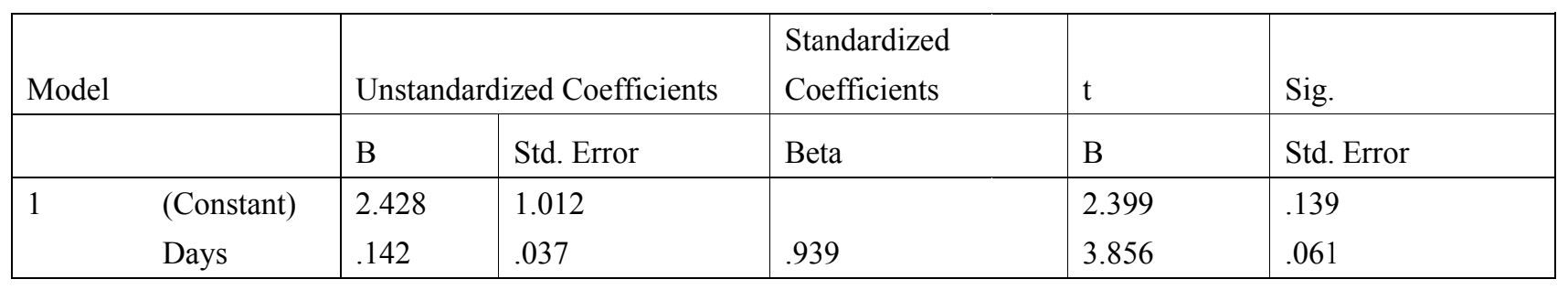

a Dependent Variable: EPPRICEDIF

Model Summary: Regression Value of \% Difference in Call Option prices:

\begin{tabular}{|c|c|c|c|c|}
\hline Model & $\mathrm{R}$ & R Square & Adjusted R Square & Std. Error of the Estimate \\
\hline 1 & $.973(a)$ & .946 & .920 & 2.25733 \\
\hline
\end{tabular}

a Predictors: (Constant), Days

Model Summary: Regression Value of \% Difference in Put Option prices:

\begin{tabular}{|l|l|l|l|l|}
\hline Model & R & R Square & Adjusted R Square & Std. Error of the Estimate \\
\hline 1 & $.323(\mathrm{a})$ & .104 & -.344 & 16.76026 \\
\hline
\end{tabular}

a Predictors: (Constant), Days

Regression analysis is a method to deal with the relationship between independent variable and dependent variable, in this study days to expiry i.e. 7, 15, 30 and 43 are considered as independent variable while call and put option prices are dependent over the change in time to expiry. On the basis of outcome of regression analysis we can say that time to expiry and call option prices have positive relationship as it has been one of the basic principle of B-S-M model. Here R value is .905 and R Square .819 in case of European Call Option price average difference that says that if time to expiry decreases call premium decreases and vice versa. Similar relationship has been observed in case of put option behaviour with $\mathrm{R}$ value .939 and $\mathrm{R}$ Square value .881 which indicate close relation ship between the put option premium and days to expiry. Based on the regression value we can say that put option price rellationship with time to expiry is more strong than the call option price. This relationship is also explain by theta $(\theta)$ Greek under the B-S-M model. Our study based on regression analysis prove the validity of B-S-M model, though when it comes to percentage difference in the put option prices analaysis says that it is not necessary that always reduction in time will reduce put option price and increase in time to expiry will increase put option price as the Adjusted R Square value is -.344 .

So far anova is concern the table value for 1 degree of freedom for numerator and 2 degree of freedom of denominator for $5 \%$ level of significance is 18.5 and computed value is 9.05 for call option price and 14.868 for put option price, therefore null hypothesis is accepted in both the cases. 
Paired Samples Statistics

\begin{tabular}{|l|l|l|l|l|l|}
\hline \multicolumn{2}{|l|}{} & Mean & N & Std. Deviation & Std. Error Mean \\
\hline Pair 1 & CPD & 43.8525 & 4 & 7.95835 & 3.97917 \\
\hline & PPD & 23.1525 & 4 & 14.45960 & 7.22980 \\
\hline
\end{tabular}

Paired Samples Correlations

\begin{tabular}{|l|l|l|l|l|}
\hline \multicolumn{2}{|l|}{} & $\mathrm{N}$ & Correlation & Sig. \\
\hline Pair 1 & CPD \& PPD & 4 & .102 & .898 \\
\hline
\end{tabular}

Paired Samples Test

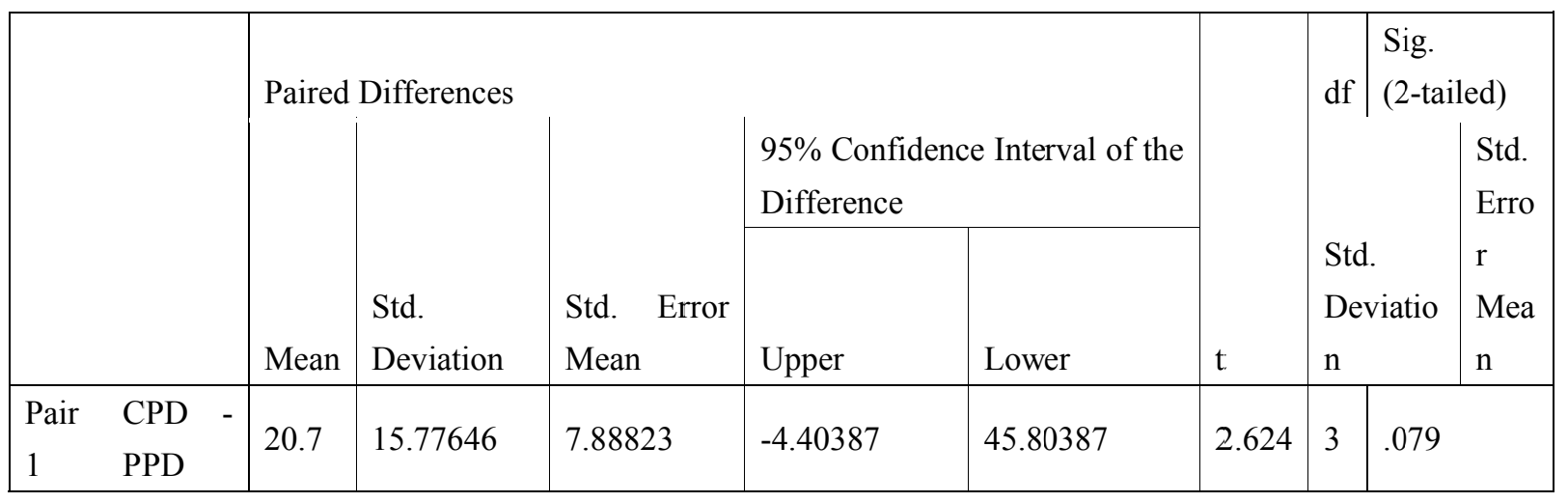

CPD: Call price Average \% Difference with Actual Price

PPD: Put price Average \% Difference with Actual Price

Table value at $5 \%$ significance level for $3 \mathrm{DF}$ is 3.182 while computed $\mathrm{t}$ value is 2.624 that indicates that B-S-M model is identical for both call and put option pricing henceforth $\mathrm{H} 3$ is accepted.

Hypothesis can be concluded in the following manner:

H1: There is no significant difference between the expected options price computed by B-S-M Model by taking historical volatrility and actual price determined by market forces. Result Accepted.

H2: There is no impact of length of time to expiry on the difference between expected and actual options price. Rejected/ Not Accepted because for both call and put there is stong corelation between time to expiry and price.

H3: Black Schole Merton model gives identical result for both call option price as well as put option price. Accepted

\section{Recommendations for the Application of Model:}

- Traders need to be cautious while using Black-Schole-Merton model for predicting the price of put option as the averge variation in the prices are higher in case of put option compared to call option. 


\section{Macrothink Institute ${ }^{\mathrm{TM}}$}

- Traders should avoid using Black-Scholes-Merton model when days to expiry are nearer as the relative / percentage difference in prices increases highly with the decrese in number of days to expiry. Using Black-Scholes-Merton model when days to expiry are less will lead to high percentage difference in prices between the expected and actual values of call and put options

- Traders should use Black-Scholes-Merton model when days to expiry are more, as they seem to provide better results.

\section{Conclusion}

On the basis of the real time data collected from the derivative segment of NSE, the call and put prices of stock options have been computed and compared with the actual call and put prices of stock options. The difference between the expected and actual values were found and the results of Black-Scholes-Merton model have certain relationship with the historical annual volatility and the market capitalization of the stock. It is also found that the difference in prices increases as the number of days to expiry decreases and it also has been observed that Black-Scholes-Merton model provides better results for call options when compared to put options.

From the research it is found that the feasibility of Black-Scholes-Merton model for stock options trading in NSE India market is very low. As the prices predicted by Black-Scholes-Merton model seems to vary highly from the actual values. At present using this model would lead the possibility of price differenciation in Indian derivative market as market is driven by large number of macro economic factors as well as the emotions of the traders and investors. Therefore there is need to bring more reform in this model to make it feasible for Indian stock option products.

\section{Refernces}

Black, F., \& Scholes, M. (1972). The valuation of option contracts in a test of market efficiency. Journal of finance, 27(3), 399-417. http://dx.doi.org/10.2307/2978484

Black, F., \& Scholes, M. (1973). The pricing of options and corporate liabilities. Journal of political economy, 81(4), 637-659. http://dx.doi.org/10.1086/260062

Blattberg, R. C., \& Gonedes, J. (1974). A comparison of the stable and student distributions as statistical models for stock prices. Journal of business, 47(2), 244-280. http://dx.doi.org/10.1086/295634

Buraschi, A., \& Jackwerth, J. (2001). The price of a smile: Hedging and spanning in option markets. Review of financial studies, 14(2), 495-527. http://dx.doi.org/10.1093/rfs/14.2.495

Chen, R., \& Palmon, O. (2005). A Non-Parametric Options Pricing Model: Theory and Empirical Evidence. Review of Quantitative Finance and Accounting, 24(1),115-134. http://dx.doi.org/10.1007/s11156-005-6333-2

Copeland, T., Weston, J., \& Shastri, K. (2005). Financial theory and corporate policy (4 ed.). New York: Pearson Addison Wesley. 
Das, S. R., \& Sundaram, R. K. (1999). Of Smiles and Smirks: A Term Structure Perspective. Journal of financial and quantitative analysis, 34(2), 211-239. http://dx.doi.org/10.2307/2676279

Draper, N., \& Smith, H. (1981). Applied Regression Analysis (2nd edn). New York: Wiley.

Duffie, D., Pan, J., \& Singleton, K. J. (2000). Transform analysis and asset pricing for affine jump-diffusions. $\quad$ Econometrica, $\quad 68(6), \quad 1343-1376$. http://dx.doi.org/10.1111/1468-0262.00164

Dumas, B., Fleming, J., and Whaley, R. E. (1998). Implied volatility functions: empirical tests. Journal of finance, 53(6), 2059-2106. http://dx.doi.org/10.1111/0022-1082.00083

Finnerty, J. E. (1978). The Chicago Board Options Exchange and market efficiency. Journal of finance and quantitative analysis, 13(1), 29-38.

Galai, D. (1977). Tests of market efficiency of the Chicago Board Options Exchange. Journal of business, 50(2), 167-197. http://dx.doi.org/10.1086/295929

Geske, R. (1979). The valuation of compound options. Journal of financial economics 7(1), 63-81. http://dx.doi.org/10.1016/0304-405X(79)90022-9

Geske, R., R, Roll., \& Shastri, K. (1984). Over-the-counter option market dividend protection and "Biases" in the Black-Scholes model: A note. Journal of finance, 38, 1271-1277. http://dx.doi.org/10.1111/j.1540-6261.1983.tb02295.x

Hull, J., \& White, A. (1987). The Pricing of Options on Assets with Stochastic Volatilities. Journal of finance 42(2), 281-300. http://dx.doi.org/10.1111/j.1540-6261.1987.tb02568.x

Johnson, H., \& Shanno, D. (1987). Option pricing when the variance is changing. Journal of financial and quantitative analysis, 22(2), 143-151. http://dx.doi.org/10.2307/2330709

Macbeth, J. D., \& Merville, L. J. (1979). An empirical examination of the Black-Scholes Call option pricing model. Journal of finance, 34(5), 1173-1186. http://dx.doi.org/10.1111/j.1540-6261.1979.tb00063.x

MacBeth, J. D., \&Merville, L. J. (1980). Tests of the Black-Scholes and Cox call option valuation models. Journal of finance, 35(2), 285-301. http://dx.doi.org/10.1111/j.1540-6261.1980.tb02157.x

Naik, V., \& Lee M. (1990). General equilibrium: Pricing of options on the market portfolio with discontinuous return. Review of financial studies, 3, 493-521. http://dx.doi.org/10.1093/rfs/3.4.493

Peiro, A. (1994). The distribution of stock returns: International evidence. Applied financial economics, 4(6), 431-439. http://dx.doi.org/10.1080/758518675

www.nseindia.com 